\title{
Precautionary Principle Through the Obligations of Marine Insurance for Oil Tankers in the Indonesian Legal System
}

\author{
Elly Kristiani Purwendah \\ \{elly_kristiani@yahoo.co.id\}
}

Wijaya Kusuma UniversityPurwokerto, J1. Raya BejiKarangsalam No.25, Dusun III, KarangsalamKidul, KedungBanteng, KabupatenBanyumas, Jawa Tengah 53152Indonesia

\begin{abstract}
Marine Insurance is a priority need nowadays considering Indonesia is an archipelagic state. Marine insurance related to tanker transportation regulated through the International Convention on Civil Liability for Oil Pollution Damage 1969 and the Protocol 1992 (CLC 1969). The CLC Convention was established to ensure adequate compensation for oil pollution victims due to tanker accidents. The Convention imposes liability on shipowners for the environmental losses from oil pollution. The Convention requires insurance for large tankers weighing 2000 tons or more for the prevention of damage to the marine environment. Indonesia, as a state ratifying the CLC 1969 must apply the obligations in the national legal system as the fulfillment of the precautionary principle of oil pollution by tanker accident. The approach method was normative juridical and the secondary data used in the discussion of the paper. Marine insurance in the form of the Insurance of Protection and Indemnity (P \& I) as the protection for ship owners, operators, or tenants of legal liability to third parties is the application of Precautionary Principle in order to protect the rights of coastal states on their marine environments in international shipping lanes which are hazardous transports. The use of the principle included in the Circular Letter of the Minister of Transportation no. AL.801/ $1 / 2$ Phb 2014 concerning the obligation to ensure vessels using vessel removal insurance and compensation protection. The nature of the imposition of vessel liability insurance addressed to ships in general.
\end{abstract}

Keywords: Precautionary Principle, Marine Insurance, Indonesian Legal System

\section{Introduction}

Precautionary Principle is an instrument for preventing pollution or destruction related to the problems faced by policymakers, namely the uncertainty of science in estimating environmental impacts. Precautionary principles implemented into the ecological law to discipline the business of oil tankers to take preventive measures of prevention, response, and recovery of ecological damages [1]. Precautionary principles are vital on the environmental crisis management, or else, policy and laws. In the era of high awareness towards sustainable development and environment preservation, policymakers must make decisions despite the uncertainty of science in implementing environmental impacts, and thus, the precautionary principle is applied[2]. This due to the precautionary principles reflects the thought of action before a loss arises regardless of the inconclusive state of scientific consensus[3]. 
The precautionary principles seek to predict the uncertainty of environmental impact estimates which are understood through scientific, pragmatic, theoretical difficulties yet with a caveat of translatability to the public understanding. Practical doubt occurs if experts do not have enough time and money to conduct proper risk assessment and risk management plan, whereas decision-makers need immediate results or information required in decision making[4]. Scientific uncertainty is the difference between theoretical views among environmental science experts and the occurrence of different interpretations of data and findings. The change of complexity in an open system occurs because nature is difficult to predict or to estimate accurately and somewhat incomprehensible to public perception [5]. However, the policymakers seem to be ignorant about this problem as they associate inconclusiveness of scientific inquiry to false claims, to which such attitude is often caused by the high rate of science illiteracy within the policymakers[6]. The uncertainty of apparent environmental losses that are difficult to be unanimously concluded and aggravated by the ignorance of science-illiterate politicians are what hinder the progress of ecological disaster management to oil tanker businesses [7]. Therefore, there is a need for proper communication culture which can translate such scientific information within the policy-making table[8].

The precautionary principle is essential to be implemented concretely in the cases of oil pollution by tanker. Oil transport is vital to the world economy, and it is big business. Oil transport by sea estimated at $40 \%$ of the total trade transported by sea. As for the law, the activity of oil transport is legally bound to the international laws of environmental law and law of the sea in which marine pollution, especially oil-spill pollution, is reciprocally regulated by both laws[9]. The ships annually spill one to two million tons of oil in the marine environment. Oil spills into the sea are caused by the operation of ships and ship accidents resulting in degradation of the quality of the marine environment.

Guided by the precautionary principle, as mentioned above, the paper was intended to analyze how the Indonesian legal system answers the oil pollution problem by tanker related to the application of the precautionary principle. The principle was applied through an insurance obligation in which it is understood that insurance provides the service in the mitigation of risks for loss, loss of benefits, and legal liability to third parties arising from uncertain events (Article 3 on the type of insurer businesses, Law Number 2 of 1992 on Insurance).

\section{Method}

The research of this paper is based on an inquiry to secondary data. In legal studies context, secondary data consists of legal literature that are legislations, statutes, legal expert commentaries, and research regarding the issue of marine insurance and precautionary principles within the Indonesian law. The approach used in this paper will be doctrinal[10]in a sense which construes the notion of the precautionary tenets within the international laws and Indonesian law, and how the legal doctrines of both affect the implementation of the precautionary principles in Indonesia. The objective of the research is reform-oriented by which the law is intensively evaluated to propose critics and preliminary conclusion, which offers future reformative ideas toward the issue [11].

\section{Findings}


The Act Number of 32, 2009 about Environmental Protection and Management (UUPPLH) in Article 2 states that the principle of environmental protection and management is the principle of sustainability and preservation and the law of justice. The explanation of the article says that; the principle of sustainability and conservation is, "that anyone carries the obligations and responsibilities to future generations and his/her fellowmen in one generation by conserving the carrying capacity of ecosystems and improving the quality of the environment." On the other hand, the purpose of environmental protection and management is to ensure the fulfillment of the principle of justice, the justice of present and future generations, and the realization of sustainable development.

The precautionary principle, as outlined in various international documents, is regarded as a guide for decision making in the situations of scientific uncertainty. In general, the precautionary principle is formulated in the statement that in the event of the threat of severe or irreversible damage, decision-makers cannot use the uncertainty or scientific evidence as a reason to delay the prevention of the danger. The principle was subsequently adopted in various declarations or agreements on marine protection in Europe, which is further recognized, approved, and applied in international or regional conventions and meetings related to maritime security. From the marine protection regime, the precautionary principle gains full recognition as one of the principles of environmental management recognized in the 1992 Rio Declaration for subsequent adoption in almost all international agreements on environmental protection that emerged after the Rio Declaration.[12]

The precautionary principle as an environmental management principle is generally recognized to be raised in Indonesian legislation through Article $2 \mathrm{f}$ of the Law of Environmental Protection and Management (UUPPLH) which states that environmental protection and management are based on the precautionary principle. In the explanation, it is mentioned that precautionary principle is defined that the uncertainty on the impact of business and activity due to limited mastery of science and technology is not a reason to delay the measures to minimize or avoid threats to pollution and environmental damage.

The precautionary principle is implemented through insurance obligations for every tanker transporting oil. Insurance of boats plays a vital role to guarantee the interests of the marine environment in the context of social-ecological justice as outlined in Article 33 Paragraph (3) of the 1945 Constitution. One of the international conventions used as the basis for the settlement of oil pollution cases by tanker is the International Convention on Civil Liability for Oil Pollution Damage 1969/ CLC 1969 amended with CLC 1992. The Convention requires that tanker owners be personally liable for oil pollution from their ships in the territories of state parties and take preventive measures to minimize such damage through insurance[13].

In practice, financial compensation and compensation system are called indemnifying. Marine insurance liability is based on the predictability that an insurance company may forecast risks and efforts related to risk management. Ideally, the contracting parties in the insurance have mutually good faith (utmost good faith) to disclose the facts against the claim for loss. Under the circumstances, insurance is understood as a contract of indemnity. Agreement of payment in the form of insurance obligations is required as the necessary fund for losses due to oil pollution by tanker accident. Oil pollution insurance claims due to tanker ships should be given directly and strictly (strict liability) as a contingent liability with the restrictions on the number of compensation payments set first[14].

Tanker Insurance of P \& I or Protection Indemnity is an insurance that protects shipowners, operators or tenants for their legal liability to third parties. The Insurance provides a legal guarantee to third-party liability arising from the ownership or operation of 
vessels. The extent of P \& I guarantees used to ensure the risk or uncertainty of pollution is the guarantee of legal pollution liability to ensure the occurrence of contamination and waste and pollution cleanup.[15] The coverage of the $\mathrm{P} \& \mathrm{I}$ insurance for the risk obligations set out to be imposed directly related to the operation of vessels.

The coverage of insurance for the operation of tanker transportation becomes an urgent need considering the interest of protection in compliance with precautionary principles in predicting the risks of oil pollution occurred. Insurance as a preference that is required initially as a liability is a safeguard of business activities against possible infection. Insurance is an economic unit that tackles risk by combining various parties who have the same situation in the face of unexpected financial loss arising from management (economic sense). Insurance is an agreement between the insurer and the insured in which the insurer with a consideration (premium) will take over the financial losses incurred by the insured arising unexpectedly (legal sense). Insurance is a means to reduce business risk by collecting exposure units in sufficient amount to make individual losses predictable.

Article 246 of the Code of Commercial Law (KUHD) states that insurance or coverage is an agreement by which an insurer binds himself to the insured by accepting a premium to provide compensation to him for damages and the loss of expected profit which he may suffer due to an uncertain event. The extent of the insurance coverage agreement in Indonesia under Article 247 of KUHD covers the danger of fire, the risk that threatens the harvested crops, the life of one or more persons, the threat of the sea and slavery, and the danger that threatens the transport inland, river, and terrestrial waters. Furthermore, the definition of insurance is stated in Law No. 2 of 1992 on Insurance Business Article 1 point 1 which is reported as an agreement between two or more parties by which the insurer binds himself to the insured by accepting an insurance premium, to provide reimbursement to the insured due to loss, damage, or loss of expected profit, or legal liability to a third party which may be subject to the insured, arising from an uncertain event, or to provide a payment based on the death or life of an insured person.

As a follow-up on the issue of compensation claims for the threat of oil pollution of the marine environment, the General Assembly of the United Nations established a Legal Committee to discuss the matters of law in terms of the responsibility and liability for compensation to the damage/ pollution of marine environment caused by oil due to tanker accidents. The Legal Committee discusses the rights of coastal states to take pollution measures. The draft of the legal committee is brought to the International Conference, which explains the responsibility of compensation for the pollution of the marine environment by oil due to tanker accidents. The burden of strict liability in the understanding of oil pollution by tankers is applied by the application of the ceiling of the maximum limitation amount of compensation using the principle of res ipsaloquiturstating that the type of liability relieves the plaintiff from the burden of proof and increases the likelihood that external costs will be imposed upon the enterprise causing them [16].

Insurance claims are limited to the notion that the responsible party is imposed only to a specific limit. Indonesia adopts a ceiling in strict liability, because the explanation of Article 35 paragraph (1) of the Law of Environmental Protection and Management (UUPLH) and the description of Article 88 of the Law of Environmental Protection and Management (UUPLH) explain that the amount of compensation that can be imposed to environmental polluters or destroyer may be determined to some extent. The understanding of some limits according to the applicable laws and regulations requires the obligation of insurance for the businesses and activities concerned which have provided environmental funds. The CLC 1969 is a Convention that regulates the compensation insurance of marine 
environment pollution by oil due to tanker accident. The Convention was adopted on 29 November 1969 and entered into force on 19 June 1975. The Convention applies to the pollution of the marine environment in the territorial waters of participating States. Some guarantees can conduct compensation insurance in marine pollution caused by oil from tankers according to international law:

a) Under the CLC 1969, it determines the responsibility or contribution of the shipowner to the infection coming from the vessel. The limit of compensation liability is the US \$20 million and applies only to the tankers carrying persistent oil.

b) The Fund Convention establishes the IOCP Fund to compensate damages for the damages caused by pollution when the funds from the CLC Convention are insufficient. The Fund Convention is funded by the members (Country) of the Fund Convention through the calculation of the amount of persistent oil received. The limits of liability in respect of the compensation of the Fund Convention to the US $\$ 84$ million are included the amount paid by the CLC Convention.

The International Conventions are necessarily the transitional obligations of the polluters (in this case, the tanker companies/ vessel owners) to the third party to perform their duties according to the polluter pays principle (the principle that the polluter is obliged to pay compensation for pollution as the risk of its activities). The transfer of the obligation to pay compensation is carried out by the third party (in this case, the insurance which has been previously agreed upon and become a requirement in the tanker shipping agreement). The obligation to pay for pollution compensation by tanker owners as regulated in the international convention is viewed from the interests of its initiators. There is a convention as a result of the states (IMCO / IMO) made to avoid any legal complexity that may arise in the case of oil spills and to meet the needs of international regulations. The IMO is rapidly working to develop a uniform international instrument by regulating the liability procedures in the event of an oil spill [12].

The relevant issue in the convention is the private obligation for the source of pollution to the victims about the civil liability of individual actors. Allan Khee-Jin Tan states[17]:

"Liability thus refers to the conventional regime of civil liability, facilitating the compensation of pollution damage victims by private, non-state interest, particularly the shipowner and his insurer. The issue of criminal liability under the national laws of states where pollution is suffered falls outside the present inquiry".

The underwriting responsibility in insurance in practice is limited through an insurance company with a certain amount of limit and the payable circumstance limit. Such reinsurance practices become common as one of the characteristics of the modern world, particularly the transportation of oil through tankers to account for the risks that occur with oil spills. Cyril Hodge states the main objective of reinsurance as follows[18]:

"From the point of view of a ceding office, the real purpose of reinsurance is to equate the loss curve: to enable it to preserve its net account on a balanced footing, so as not to show a very favorable result one year occur periodically, but judicious reinsurance softens their incidence, and helps to stabilize the net results, thereby increasing the prestige of the office concerned. To achieve this stability, the acceding office must be prepared to go for a profit it might have kept for itself. Payment of a premium is required to obtain reinsurance over; a direct underwriting office thus surrenders part of the benefits it would make in good years to recoup itself for losses it would otherwise incur more heavily in bad years. The portion of profits which the ceding office forgoes is the reward the reinsurer obtains to compensate for the liabilities it 
assumes. It is axiomatic to a reinsurer that the broadest possible distribution of risk inessential.

In the national legal system, the tanker's insurance liability is individually not regulated as an action to overcome the uncertainty of pollution related to how to claim, who has the right to request, and how to calculate the claim (minimum and maximum constraints by the CLC convention standard). The CLC is only mentioned in the Presidential Regulation No. 109 of 2006 on Emergency Handling of Oil Spill at Sea in,first, considering point 12 (the Presidential Decree (Keppres) Number 18 of 1978 on Ratifying the International Convention on Civil Liability for Oil Pollution Damage 1969, the State Gazette of the Republic of Indonesia of 1978 Number 28) and, second, point 13 of Presidential Decree No. 46 of 1986 on the Ratification of the International Convention for the Prevention of Pollution from Ships 1973 and the Protocol 1978 relating to the International Convention for the Prevention of Pollution from Ships 1973, and the State Gazette of the Republic of Indonesia of 1986 number 59.

Technically, the arrangement of vessel insurance is stipulated in Law No. 17 of 2008 on Shipping (UUP) in Article 203 paragraph (4) which states that "to guarantee the obligations referred to in Paragraph (1) and Paragraph (2), a shipowner shall insure his vessel." The insurance obligation is an obligation for the framework of ships in general and is not specifically for tanker oil pollution. Then, it is followed up by the regulations in related institutions, namely the Ministry of Transportation through the Letter of the Minister of Transportation of the Republic of Indonesia No. AL.801/ 1/2 PHB 2014 dated December 8, 2014 which states that: pursuant to the provisions of Article 203 Paragraph (5) of Shipping Law (UUP), Article 119 of the Government Regulation on Navigation and Article 18 of the Minister of Transportation Regulation No. 71 of 2013 on Salvage and/ or Under Water Works, it is regulated that the shipowner is required to ensure his vessel with vessel removal insurance and/or protection and compensation. To the shipowner as mentioned above, those who do not insure his boat shall be liable to administrative sanctions in the form of a. Warning; or b. The halt of permits; or c. Revocation of license. The insurance liability is reserved for shipowners who have motorboats of the gross tonnage size of more than 35 GT (thirty-five gross tonnages), applicable on March 1, 2015.

The Financial Services Authority (OJK) encourages insurance liability for vessels (in general) to the Directorate General of Sea Transportation by the Minister of Transportation Regulation Number 71 of 2013 on Salvage and Underwater Works. So far, Indonesian ships have purchased P \& I insurance policies in Singapore or London, and now they are required to buy them in insurance companies in Indonesia. Besides, it is also necessary to consolidate the product format and uniformity of the P \& I insurance policy. The marketing of the products will be directed through the implementation of a consortium consisting of several insurance companies; making it more effective in monitoring and facilitating the consumers when a claim occurs. The regulator of the financial industry will cooperate with the Ministry of Transportation. The OJK will invite the General Insurance Association of Indonesia to conduct coordination including with the practitioners and the P \& I club of Indonesia to facilitate the implementation of the obligation to purchase policies of $\mathrm{P} \& \mathrm{I}$ in Indonesia. P \& I generally guarantees unrecognized losses. It is different from vessel frame or cargo insurance that insures the possible risks of insured objects. P \& I Insurance ensures the responsibility for third parties which are not guaranteed in vessel frame insurance. The hazards to the third party include the responsibility of the carrier to the cargo owner when damaged, the shipowner's responsibility for the collision occurred between ships, environmental pollution to shipwreck. 
From the study above, a particular precautionary principle for tanker related to the insurance liability is generally applied without distinction of ship type. The obligation of ship insurance as a precautionary principle go forward for all types of vessels with the gross tonnage weight of more than 35 (thirty-five gross tonnage) with the purpose of insurance of vessel removal insurance and protection and compensation. Technically, as for the oil tanker, the implementing regulation of Presidential Decree Number 18 of 1978 on Ratifying International Convention on Civil Liability for Oil Pollution Damage 1969, the State Gazette of Republic of Indonesia of 1978 Number 28,the Presidential Decree Number 46 of 1986 on the Ratification of the International Convention for the Prevention of Pollution from Ships 1973, the Protocol of 1978 relating to the International Convention for the Prevention of Pollution from Ships1973, and the State Gazette of the Republic of Indonesia of 1986 Number 59 have not been enacted.

The regulations above do require the compensation insurance for marine pollution, but the problem is that the instruments have not been regulated technically on special protection for the tanker, how the claim procedure, and who is entitled to make a claim. In practice, the conditions lead to the difficulty of prosecuting applications of compensation as well as leaving the problem of pollution of the marine environment. It is expected that, in the future, the relevant institutions (the Ministry of Environment and Forestry) can formulate technical regulations in the form of the claim procedure of tanker oil pollution insurance.

\section{Conclusion}

Precautionary Principle through Marine Insurance Liability for Oil Tanker in Indonesian Legal System shall be regulated in the Presidential Decree Number 18 of 1978 on Ratifying International Convention on Civil Liability for Oil Pollution Damage 1969, the State Gazette of Republic of Indonesia of 1978 Number 28, the Presidential Decree Number 46 of 1986 on the Ratification of the International Convention for the Prevention of Pollution from Ships 1973, the Protocol of 1978 relating to the International Convention for the Prevention of Pollution from Ships 1973, and the State Gazette of the Republic of Indonesia of 1986 Number 59. Technically, the precautionary principle is emphasized through the obligation of insurance as stated in the Letter of the Minister of Transportation of the Republic of Indonesia No. AL.801/ 1/2 Phb 2014, dated December 8, 2014 which states that;pursuant to the provisions of Article 203 Paragraph (5) of Shipping Law (UUP), Article 119 of the Government Regulation on Navigation and Article 18 of the Minister of Transportation Regulation No. 71 of 2013 on Salvage and/ or Under Water Works, it is regulated that the shipowner is required to ensure his vessel with vessel removal insurance and/ or protection and compensation. To the shipowner as mentioned above, those who do not insure his vessel shall be liable to administrative sanctions in the form of a. Warning; or b. A halt of permits; or c. Revocation of permit. The insurance liability is reserved for shipowners who have motorboats of the gross tonnage size of more than 35 GT (thirty-five gross tonnages), applicable on March 1, 2015. The Financial Services Authority (OJK) recommends imposing liability insurance on vessels (in general) to the Directorate General of Sea Transportation based on the Regulation of the Minister of Transportation No. 71 of 2013 on Salvage and Under Water Works. The nature of the imposition of liabilities is still addressed to the vessel in general, so it still requires the arrangement of individual insurance for tankers. Besides, the legal instruments related to the regulation of the liability and procedures for the filing of the insurance claim for tanker oil pollution are required. 


\section{References}

[1] J. Verschuuren and L. Kotze, The Role of Sustainable Development and the Associated Principles of Environmental Law and Governance in the Anthropocene. London: Hart Publishing, 2017.

[2] J. S. Chang and J. H. Sung, "Scientific Uncertainty as a Threshold of Precautionary Principle," 미국헌법연구, 2017.

[3] E. Persson, "What are the core ideas behind the Precautionary Principle?," Sci. Total Environ., 2016.

[4] T. Aven, "Risk assessment and risk management: Review of recent advances on their foundation," European Journal of Operational Research. 2016.

[5] R. Jefferson, E. McKinley, S. Capstick, S. Fletcher, H. Griffin, and M. Milanese, "Understanding audiences: Making public perceptions research matter to marine conservation," Ocean Coast. Manag., 2015.

[6] C. Cvitanovic, A. J. Hobday, L. van Kerkhoff, S. K. Wilson, K. Dobbs, and N. A. Marshall, "Improving knowledge exchange among scientists and decision-makers to facilitate the adaptive governance of marine resources: A review of knowledge and research needs," Ocean and Coastal Management. 2015.

[7] J. van Leeuwen, J. Raakjaer, L. van Hoof, J. van Tatenhove, R. Long, and K. Ounanian, "Implementing the Marine Strategy Framework Directive: A policy perspective on regulatory, institutional and stakeholder impediments to effective implementation," Mar. Policy, 2014.

[8] N. A. Rose and E. C. M. Parsons, "Back off, man, I'm a scientist!' When marine conservation science meets policy," Ocean Coast. Manag., 2015.

[9] J. D. Fry and I. Amesheva, "Oil Pollution and the Dynamic Relationship between International Environmental Law and the Law of the Sea," SSRN Electron. J., 2018.

[10] T. A. Christiani, "Normative and Empirical Research Methods: Their Usefulness and Relevance in the Study of Law as an Object," Procedia - Soc. Behav. Sci., 2016.

[11] R. West, "The contested value of normative legal scholarship," J. Legal Educ., 2016.

[12] D. Soto-Oñate and G. Caballero, "Oil spills, governance and institutional performance: The 1992 regime of liability and compensation for oil pollution damage," Journal of Cleaner Production. 2017.

[13] J. Harrison, "Regime pluralism and the global regulation of oil pollution liability and compensation," Int. J. Law Context, 2009.

[14] J. Adshead, "The application and development of the Polluter-Pays Principle across jurisdictions in liability for marine oil pollution: The tales of the 'Erika' and the 'Prestige,"' J. Environ. Law, 2018.

[15] S. Knapp and C. Heij, "Evaluation of total risk exposure and insurance premiums in the maritime industry," Transp. Res. Part D Transp. Environ., 2017.

[16] S. Ulfah, "Strict Liability Principle in Environmental Legal System," J. Law, Policy Glob., vol. 71, pp. 100-111, 2018.

[17] A. K.-J. Tan, Vessel-Source Marine Pollution. 2005.

[18] V. Dover, A Handbook of Marine Insurance. London, 1970. 
